\title{
COMPUTATIONAL MODELING FOR IRRIGATED AGRICULTURE PLANNING. PART I: GENERAL DESCRIPTION AND LINEAR PROGRAMMING
}

\section{JOÃO C. F. BORGES JÚNIOR ${ }^{2}$, PAULO A. FERREIRA ${ }^{3}$, CAMILO L. T. ANDRADE ${ }^{4}$, BETTINA HEDDEN-DUNKHORST ${ }^{5}$}

\begin{abstract}
Linear programming models are effective tools to support initial or periodic planning of agricultural enterprises, requiring, however, technical coefficients that can be determined using computer simulation models. This paper, presented in two parts, deals with the development, application and tests of a methodology and of a computational modeling tool to support planning of irrigated agriculture activities. Part I aimed at the development and application, including sensitivity analysis, of a multiyear linear programming model to optimize the financial return and water use, at farm level for Jaíba irrigation scheme, Minas Gerais State, Brazil, using data on crop irrigation requirement and yield, obtained from previous simulation with MCID model. The linear programming model outputted a crop pattern to which a maximum total net present value of R \$ 372,723.00 for the four years period, was obtained. Constraints on monthly water availability, labor, land and production were critical in the optimal solution. In relation to the water use optimization, it was verified that an expressive reductions on the irrigation requirements may be achieved by small reductions on the maximum total net present value.
\end{abstract}

KEYWORDS: irrigation requirement, financial return, simulation model.

\section{MODELAGEM COMPUTACIONAL PARA PLANEJAMENTO EM AGRICULTURA IRRIGADA. PARTE I: DESCRIÇÃO GERAL E PROGRAMAÇÃO LINEAR ${ }^{1}$}

RESUMO: Modelos de programação linear são ferramentas eficazes de suporte ao planejamento inicial ou periódico de empreendimentos agrícolas, requerendo, todavia, coeficientes técnicos que podem ser obtidos por modelos computacionais de simulação. Este trabalho, dividido em duas partes, aborda o desenvolvimento, a aplicação e os testes de metodologia e da modelagem computacional de uma ferramenta de auxílio ao planejamento da exploração agrícola irrigada. Teve-se o objetivo de desenvolver e aplicar, com análise de sensibilidade, um modelo de programação linear plurianual para otimização do retorno financeiro e uso da água, em nível de propriedade rural no perímetro de irrigação do Jaíba - MG, utilizando dados de requerimento de irrigação e produtividade de culturas, obtidos com o modelo de simulação MCID. O modelo de programação linear indicou um padrão de cultivo para o qual se obteve o máximo valor presente líquido total, de $\mathrm{R} \$ 372.723,00$ para o período de quatro anos. Restrições quanto à disponibilidade mensal de água, mão-de-obra, terra e produção foram críticas na solução ótima. Em relação à otimização de uso da água, verificou-se que expressivas reduções no requerimento de irrigação podem ser obtidas com pequenas reduções no valor presente líquido total máximo.

PALAVRAS-CHAVE: requerimento de irrigação, retorno financeiro, modelo de simulação.

\footnotetext{
${ }^{1}$ Abstracted from first author's doctorate thesis. Financial support: CNPq, Capes, DAAD

${ }^{2}$ Agricultural Eng., D.Sc., Aux. Prof., Academic Unit of Garanhuns, UFRPE, Garanhuns - PE, Brazil, Phone: (0XX87) 3761.0969, jcborges@uag.ufrpe.br

3 Agricultural Eng., Ph.D., Titular Prof., Agricultural Engineering Dept., UFV, Viçosa - MG, Brazil.

${ }^{4}$ Agricultural Eng., Ph.D., Researcher, Embrapa Milho e Sorgo, Sete Lagoas - MG, Brazil.

${ }^{5}$ Agricultural Economist, Ph.D., Federal Agency for Nature Conservation, Bonn, Germany.

Received by Editorial Board on May, 14, 2007
}

Approved by Editorial Board on September, 2, 2008 


\section{INTRODUCTION}

Farmers and rural entrepreneurs have to take periodical decisions about the cultivation standards to be adopted, taking on account constraints to agriculture businesses (resources and production) and, frequently uncertainty about technical coefficients (crop yield, inputs requirements, agricultural prices, etc.) for planning period (HAZELL \& NORTON, 1986).

In the initial or periodical planning, and in the irrigated agriculture businesses management, measures shall be observed contributing to the establishment of a production scenario, able to optimize financial return, water use, or even labor demand. Linear programming is a tool applicable to cropping planning and optimization of resources allocation, such as land, water and labor, taking into account constraints about those resources availability and production (BORGES JÚNIOR, 2004; FRIZZONE et al., 2005; HAZELL \& NORTON, 1986); the latter, for instance, due to market capabilities or requirements, or capacity of products processing. In irrigated agriculture, technique has been generally applied to periods no longer than one year. (CARVALHO et al., 2000; CARVALHO et al., 1998; DANTAS NETO et al., 1997; SILVEIRA, 1993). Applications to pluriannual planning horizon are also feasible (BORGES JÚNIOR, 2004; HAZELL \& NORTON, 1986).

Generally, inquiries of cropping standard optimization and production strategies, facing to irrigated agriculture, related to financial return and water use, and linked to risk analysis based on simulations, are not commonly applied in developing countries. Among the main causes of these inquiries little diffusion, are insufficient data and involved costs, especially with personnel able to apply the analysis. Other possible cause is the unavailability of specific computational models, provided with interface addressed to irrigated agriculture, in order to help for mathematical programming models construction and risk analysis (BORGES JÚNIOR et al., 2003).

For decades the complexity related to irrigated systems planning and management has been stimulating the development of computer models as supporting tools for decision undertaking (SKAGGS, 1999; TARJUELO \& JUAN, 1999). This complexity comes from the great number of variables in the processes involved in the soil-water-plant-atmosphere system. Computational simulation models may also be efficient tools for obtaining the technical coefficients required by linear programming models and risk analysis, allowing time and material and financial resources economy gains, when reported to obtain these coefficients through experimental procedures (MEINKE et al., 2001).

This work, presented in two parts, does an approach to the development, application and tests of a methodology and a computational modeling helping for the planning of production strategies for irrigated agriculture. In this article, related to the Part I of the work, the purpose was developing and applying a pluriannual linear programming model for the optimization of the financial return and water use, regarding to rural property in the irrigation perimeter of Jaíba - MG, using required data of irrigation and crop yield obtained through MCID simulating model (BORGES JÚNIOR et al., 2008; FERREIRA et al., 2006).

\section{MATERIAL AND METHODS}

The proposed methodology applying to strategies planning for irrigated agriculture production, embraces a set of computational tools, which can be integrated, in accordance with Figure 1. 


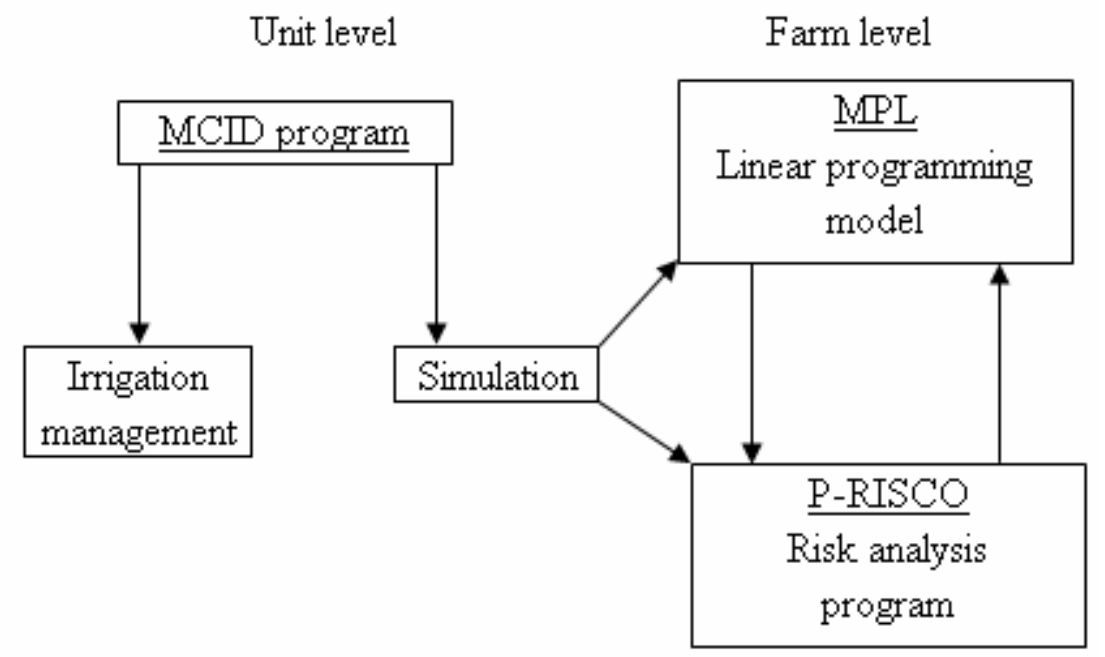

FIGURE 1. Integration scheme of computational tools applicable to production planning in irrigated agriculture.

At a parcel level or production unit, computational model MCID (BORGES JÚNIOR et al., 2008; FERREIRA et al., 2006) can be used as a supporting tool for irrigation management and to simulate the effect of different configurations of irrigation and/or drainage systems and irrigation management on crop yield, financial return and irrigation requirement, among other output variables. Simulations are carried out on a daily basis, using historical series of climatic data and information about soil, cropping, irrigation management, configurations of drainage systems to be evaluated (if drainage will be taken on account) and financial data. Crop yield is calculated considering stresses due to water deficit, water excess (when draining will be considered) and salinity, simulated from water and salts balance in the root zone.

Simulation results with MCID can, therefore, be used as technical coefficients in studies about cropping pattern optimization on farm level, related to financial return and water use, associated with risk analysis. This procedure is used in the methodology here described, and cropping pattern optimization inquiries are conducted by means of the linear programming model as focused here, and the risk analysis is based on sensitivity and risk simulations. Risk analysis technique by means of simulations is applied using the software P-RISCO (BORGES JÚNIOR, 2004), whose development, application and test are approached in Part II of this work.

Linear programming model (MPL) was implemented in the Excel ${ }^{\circledR}$ spreadsheet (Microsoft Corporation) and solved by the application of a Solver tool (Frontline Systems, Inc.). Linear programming models, typical for the problem under analysis, have the suitable size for this tool application, supporting up to 200 variables (activities) and 200 constraints. An important feature is the reasonable diffusion of the Excel software application, and therefore, it would not cause any imposition to the diffusion of computational model. Using the Excel-Solver, reports are also supplied, exhibiting primal and dual solutions, the latter supplying information about the shadow prices of the limiting constraints and reduced costs of the excluded activities.

MPL can be structured for an analysis horizon of one or more years, as established by user. An analysis horizon of three or four years will be suitable, because it embraces periods of perennial cropping development and allows a planning wider than the yearly period. Longer horizons may not be suitable due to the difficulty of the foreseeing agriculture changes in production scenarios, such as some products market, inputs cost, new cropping varieties with different technical coefficients, among other aspects.

For perennial cropping with a greater longevity, as lemon, a residual net present value can be taken into account (net present value is the parameter considered in the financial analysis to 
measure the financial return) related to the period exceeding an analysis horizon. It is important to point out pluriannual planning can and must be revised periodically, for example, every six months.

As it is common, working with planning horizons greater than a year in MPL present values of benefits and costs are used. A first objective function aims to maximize profit present value, i.e. to maximize total net present value. This objective function is expressed by:

$$
\text { maximize } U=\sum_{j=1}^{N}\left(P_{j} Y_{j}-C_{j}\right) X_{j}-C f i x
$$

where,

$\mathrm{U}$ - total net present value (profit), R\$;

$\mathrm{j}$ - integer number for activity;

$\mathrm{N}$ - number of activities;

$P_{j}$ - present value of price received for a product for the $j$-th activity, $R \$ \mathrm{~kg}^{-1}$;

$\mathrm{X}_{\mathrm{j}}$ - level of the $\mathrm{j}$-th activity or cropped area, ha;

$\mathrm{Y}_{\mathrm{j}}$ - productivity of $\mathrm{j}$-th activity, $\mathrm{kg} \mathrm{ha}^{-1}$;

$C_{j}$ - present value of costs, per area unit, for the $j$-th activity, $R \$ h^{-1}$, and

Cfix - present value of fixed costs, $\mathrm{R} \$ \mathrm{ha}^{-1}$.

Activity is defined here as based on cropping, technology, irrigation and/or drainage strategy and producer category. Aiming to simplify notation, an index for each one of the factors will not be added. Working with annual or perennial cropping is possible.

Constraints about land, labor, production and available water for irrigation are used on monthly basis. Yearly constraint on water availability for irrigation can also be used. Constraints values can be considered as variable or not, for every year.

The following composition for costs $C_{j}$ is taken into account:

- Irrigation costs (irrigation water cost and the cost of irrigation consumed energy);

- Drainage costs (drainage net maintenance), according to situation;

- Labor costs, and

- Other costs (seeds, pesticides, fertilizers, mechanized operations, other inputs and services).

Purchase costs for irrigation systems and the implementing of drainage systems (according to situation), the fixed fares of irrigation per unit area, as well as other fixed costs, incurring on work, shall be included in Cfix (eq.(1)).

Other cropping patterns can be possibly obtained with the water use optimization. The objective-function then taken into account is:

$$
\text { minimize } \mathrm{Wt}=\sum_{\mathrm{j}=1}^{\mathrm{N}_{\mathrm{y}}} \sum_{\mathrm{m}=1}^{12} \mathrm{w}_{\mathrm{jym}} \mathrm{X}_{\mathrm{j}} \quad(\mathrm{y}=1, \ldots, \mathrm{na})
$$

where,

$\mathrm{Wt}$ - total irrigation water requirement, during the whole period of analysis, $\mathrm{m}^{3}$;

$\mathrm{N}_{\mathrm{y}}$ - total number of activities in year $\mathrm{y}$;

$\mathrm{w}_{\mathrm{jym}}$ - monthly irrigation requirement for activity $\mathrm{j}$, in year $\mathrm{y}$ and month $\mathrm{m}, \mathrm{m}^{3} \mathrm{ha}^{-1}$, and

na - total number of years in the model (planning horizon).

In this case is added, as an equality constraint, the following equation for the total net present value:

$$
\sum_{j=1}^{N}\left(P_{j} Y_{j}-C_{j}\right) X_{j}-C f i x=U
$$

where, $U$ shall be varied within an interval adequate to the problem. The upper limit of this interval will be the value obtained for $U$ in eq.(1). 
In Figure 2, the area limited by lines $\mathrm{BA}$ and $\mathrm{AC}$ and by the segment of vertical axis $\mathrm{CB}$ represents the set of solutions for the cropping pattern, with $U \geq 0$, in Wt vs $U$ plan. Point $A$ is obtained using eq.(1). The line drawn between the points $\mathrm{A}$ and $\mathrm{C}$ represents the minimal irrigation requirement line or efficient boundary of $\mathrm{Wt}$ vs $\mathrm{U}$, generated by the application of eq.(2), taking into account the different values of $U$, according to eq.(3).

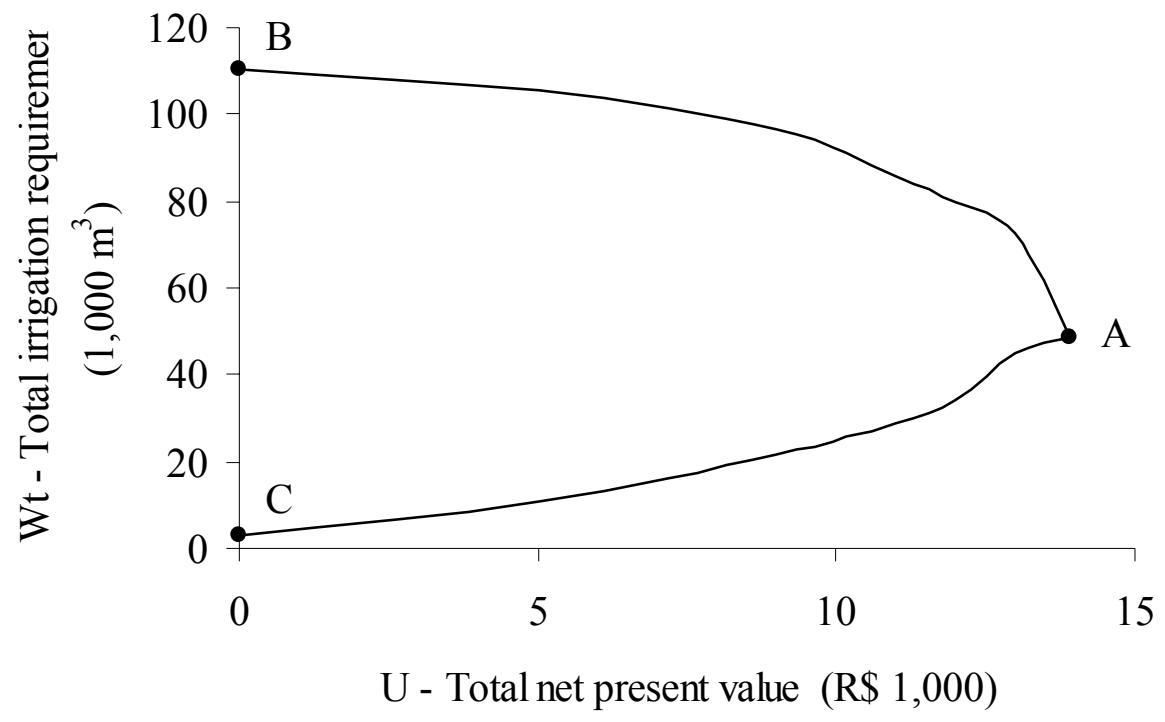

FIGURE 2. Representation of a group of solutions for the cropping pattern in the Wt vs. U plan (total irrigation requirement vs. total net present value).

In the application of the eqs. 2 and 3, some activity values can be fixed. Equation 2 can be structured to be used for specific periods, especially those periods with water scarcity risk.

\section{MPL application}

The linear programming model was applied to an entrepreneurial farm, with a total area of 20 ha, taking into account the data of the Jaíba irrigation scheme, situated at the north of Minas Gerais, Brazil, on the right bank of São Francisco river.

The planning horizon taken into account was four years. Data related to irrigation requirement and crop yield were obtained by means of simulations with the computer model MCID. The input data base is described as follows.

The following monthly climate data were obtained at the Jaíba Irrigation District - DIJ: precipitation, maximal, minimal and mean temperature averages, average relative air humidity, sunshine hours and wind speed. Unless wind speed, years 1991 to 2001 were used. For wind speed, because data were unavailable for that period, monthly average data were used. As suggested by ALLEN et al. (1998), a minimum value of $0.5 \mathrm{~m} \mathrm{~s}^{-1}$ was taken into account for wind speed. The reference evapotranspiration was calculated by means of the software REF-ET Windows Version 2.01.17 (UNIVERSITY OF IDAHO, 2003), using FAO Penman-Monteith method. Daily pluviometric data were not used directly, because of their unavailability, without costs for the considered period. Based on the historical series of daily pluviometric data of Mocambinho District, situated in the Jaíba irrigation scheme, for the period 1976 to 1992, the average values of monthly rain days number were obtained for January to December, equal to $10 ; 9 ; 4 ; 4 ; 2 ; 1 ; 1 ; 1 ; 2 ; 5 ; 5$ and 8 , respectively. So, the monthly data were converted to daily ones, based on the monthly average number of rain days.

As to the soil water retention characteristics, the average values obtained by QUARESMA FILHO (2000) were taken into account, and the water content of field capacity was equal to $0.260 \mathrm{~m}^{3} \mathrm{~m}^{-3}$ and in the wilting point equal to $0.123 \mathrm{~m}^{3} \mathrm{~m}^{-3}$. 
The elements taken into account for the cropping selection for this study were the planted area and the production value and/or the profitability reached by these crops in the years 2001 and 2002 . Data were obtained from DIJ and CODEVASF, $1^{\text {st }}$ Supervision, for the categories fruit, grains and vegetables. The crops and cropping periods (yearly crops) taken into account were (between parentheses the corresponding symbols are exhibited):

- Perennial crops: banana (B1), papaya (P1), passion fruit (MA1 e MA2) and lemon (L1).

- yearly crops: hybrid pumpkin (February to may - AJ), cotton (March to June - AL1; June to September - AL2), winter onion (April to July - CI), summer onion (November to February - CV), bean (January to March - F1; May to July - F2; October to December - F3), melon March to May ML1; August to October - ML2) and cucumber for pickling (April to June - PP).

It was taken into consideration planting happened the first day of cropping initial month, though it could be considered cropping of other month days. Cropping parameter values are listed by BORGES JÚNIOR (2004). For banana cropping, it was worked with the crop basal coefficient $\left(\mathrm{K}_{\mathrm{cb}}\right)$, whereas, for the remaining ones, it was worked with the single crop coefficient $\left(\mathrm{K}_{\mathrm{c}}\right)$. Potential crop yields (Yp) were obtained from DIJ or specialized literature.

The irrigation management criteria were differentiated for the several crops. Sprinkle, microsprinkle and drip irrigation systems were taken into account. As to the irrigation depth, the criteria taken into account were irrigating to fill $100 \%$ of the readily available soil water (RAW). In Table 1, data taken into account for irrigation management and systems are exhibited.

The constraints of MPL, whose values adopted here are hypothetical, are exhibited in Tables 2 and 3.

Though presently there are no limits about water availability for irrigation in Jaíba irrigation scheme, restrictive measures could be thought over in a scenario with a significant increase of demand in the irrigated area, or in São Francisco basin. For definitions about labor constraint, it was taken into account an availability of 20 men per day. From the labor requirement for the different tasks related to each crop (cropping, cropping treatments, irrigation management, etc.) the labor requirement for every cropping month was defined.

For production constraints, hypothetical values were taken into account, to represent both stocking or processing capacity and market capacity, as to the necessity of cropping diversification, therefore imposing higher limits to production. Another feature looked for was the necessity of some cropping minimum production, as exhibited in Table 3, and minimum values were stipulated for banana and cotton production.

TABLE 1. Input data for the irrigation systems and management: fraction of the soil surface wetted by irrigation (fwi), distribution efficiency for the desired percentage adequacy (EDad), potential efficiency of water application $(\mathrm{EPa})$ and interval between irrigations (TRega).

\begin{tabular}{|c|c|c|c|c|c|}
\hline Cropping & Irrigation System & fwi & EDad & $\mathrm{EPa}$ & TRega \\
\hline Hybrid pumpkin & Conventional sprinkle & 1 & 0.8 & 0.9 & Irrigate when $\mathrm{Dr}=100 \%$ of $\mathrm{RAW}$ \\
\hline Cotton & Conventional sprinkle & 1 & 0.8 & 0.9 & 7 days (stop 10 days before cropping) \\
\hline Banana & Conventional sprinkle & 1 & 0.8 & 0.9 & 7 days \\
\hline Winter onion & Conventional sprinkle & 1 & 0.8 & 0.9 & $\begin{array}{l}\text { Irrigate when } \mathrm{Dr}=100 \% \text { of RAW (stop } 10 \\
\text { days before cropping) }\end{array}$ \\
\hline Summer onion & Conventional sprinkle & 1 & 0.8 & 0.9 & $\begin{array}{l}\text { Irrigate when } \mathrm{Dr}=100 \% \text { of RAW (stop } 10 \\
\text { days before cropping) }\end{array}$ \\
\hline Bean & Conventional sprinkle & 1 & 0.8 & 0.9 & 7 days (stop 7 days before cropping) \\
\hline Lemon & Micro-sprinkle & 0.7 & 0.8 & 1 & 1 day $-1-1-1$ \\
\hline Papaya & Micro-sprinkle & 0.8 & 0.8 & 1 & 2 days \\
\hline Passion fruit & Drip & 0.7 & 0.8 & 1 & 1 day \\
\hline Melon & Drip & 0.8 & 0.8 & 1 & 1 day \\
\hline Cucumber & Conventional sprinkle & 1 & 0.8 & 0.9 & 3 days \\
\hline
\end{tabular}


TABLE 2. Resource constraints in the linear programming model.

\begin{tabular}{lcc}
\hline \multicolumn{1}{c}{ Constraint } & Unit & Value \\
\hline Land & há & $\leq 19$ \\
Labor (monthly) & man-days & $\leq 600$ \\
Water available for irrigation (monthly; April to September) & $\mathrm{m}^{3}$ & $\leq 15,000$ \\
Water available for irrigation (yearly) & $\mathrm{m}^{3}$ & $\leq 150,000$ \\
\hline
\end{tabular}

TABLE 3. Production constraints in the linear programming model.

\begin{tabular}{|c|c|c|}
\hline Cropping & Unit & Values \\
\hline Hybrid pumpkin & t crop $^{-1}$ & $\leq 48$ \\
\hline Cotton & $\mathrm{t}_{\mathrm{crop}^{-1}}$ & $\geq 2$ \\
\hline Banana & $t$ year ${ }^{-1}$ & $\geq 120 ; \leq 200$ \\
\hline Winter and summer onion & $\mathrm{t}$ crop $^{-1}$ & $\leq 175$ \\
\hline Bean & $t$ crop $^{-1}$ & $\leq 6$ \\
\hline Lemon & $\mathrm{t}_{\mathrm{crop}^{-1}}$ & $\leq 100$ \\
\hline Papaya & t year ${ }^{-1}$ & $\leq 250$ \\
\hline Passion fruit & $\mathrm{t}$ crop $^{-1}$ & $\leq 190$ \\
\hline Melon and pickling cucumber & $\mathrm{t}_{\mathrm{crop}^{-1}}$ & $\leq 90$ \\
\hline
\end{tabular}

The data about product prices and costs were obtained from DIJ and CODEVASF, in the last quarter of 2003. Information obtained from project irrigators was also taken into consideration to make up a basis for financial data, as exhibited by BORGES JÚNIOR (2004). A discount rate was taken into account of $12 \%$ per year to correct incomes and costs to present value.

\section{RESULTS AND DISCUSSION}

In Tables 4 and 5, results obtained with MPL are exhibited, including sensitivity analysis. In Table 4, the four right columns were obtained from Solver-Excel output reports. Reduced cost, the coefficient of every activity of objective-function and the permissible increase and decrease of these coefficients are exhibited. In the last line, the optimized value of objective-function is exhibited, (eq.(1)), i.e., total net present value (U), equal to $\mathrm{R} \$ 372,723.16$.

Reduced cost points out how much objective-function value (total net present value) would decline, if a corresponding activity, excluded from the optimal solution, would be compelled inside solution, i.e., it would be considered in the cropping pattern. The negative of the reduced cost is the quantity by which the gross margin of the corresponding activity (technical coefficient of the objective-function activity) should be increased so that activity would come in the optimal solution.

The allowable increases and decreases of the objective-function coefficient, listed in the two right columns, bound the interval in which the solution basis (the set of activities composing the optimal solution) is not changed. It stands out these intervals are obtained only taking into account the changes of the variable under inquiry. Intervals can not be taken into account for the analysis of the solution stability about simultaneous changes of more than one coefficient.

In Table 4, it can be seen papaya cropping (P1), though its remarkable profitability, with the objective-function coefficient equal to $\mathrm{R} \$ 4,374.15$ per ha, is not present in the optimal solution. This probably happened due to the high labor requirement of this activity, especially during the months of January to June, i.e., the constraint about labor, on a monthly basis, caused the exclusion of this activity from the optimal solution. Japanese pumpkin cropping (AJ), scheduled in the period of February to June, was also excluded from the optimal solution in the years two and four. In year two, a little increase of $\mathrm{R} \$ 10.99$ in the coefficient of the objective-function of this activity would cause its entry in the optimal solution, pointing out a high sensitivity for this coefficient. On the other hand, in year four, it would be necessary the coefficient of the objective-function would increase $\mathrm{R} \$ 683.32$ so as this activity would be present in the optimal solution. 
TABLE 4. Results of the linear programming model related to the optimal cropping pattern for the period of four years.

\begin{tabular}{|c|c|c|c|c|c|c|c|}
\hline $\begin{array}{l}\text { Number of } \\
\text { Activities }\end{array}$ & Activity & $\begin{array}{l}\text { Area } \\
\text { (ha) }\end{array}$ & $\begin{array}{l}\text { Gross profit } \\
\text { (R\$) }\end{array}$ & $\begin{array}{l}\text { Reduced } \\
\text { Cost } \\
\left(\mathrm{R} \$ \mathrm{ha}^{-1}\right)\end{array}$ & $\begin{array}{l}\text { Coefficient } \\
\text { Objective- } \\
\text { function } \\
\left(\mathrm{R} \$ \mathrm{ha}^{-1}\right)\end{array}$ & $\begin{array}{l}\text { Allowable } \\
\text { Increase } \\
\left(\mathrm{R} \$ \mathrm{ha}^{-1}\right)\end{array}$ & $\begin{array}{l}\text { Allowable } \\
\text { Decrease }\end{array}$ \\
\hline 1 & B1 & 3.429 & 299.17 & 0.00 & 87.26 & $13,249.64$ & $110^{30}$ \\
\hline 2 & $\mathrm{P} 1$ & 0.000 & 0.00 & $-11,502.92$ & $4,374.15$ & $11,502.92$ & $110^{30}$ \\
\hline 3 & MA1 & 5.000 & $41,925.13$ & 0.00 & $8,385.03$ & $110^{30}$ & $4,614.43$ \\
\hline 4 & MA2 & 5.000 & $48,293.14$ & 0.00 & $9,658.63$ & $110^{30}$ & $4,996.34$ \\
\hline 5 & L1 & 2.854 & $18,497.22$ & 0.00 & $6,481.63$ & $1,290.12$ & $1,246.72$ \\
\hline 13 & $\mathrm{~F} 11^{(1)}$ & 3.000 & 662.82 & 0.00 & 220.94 & $110^{30}$ & 220.94 \\
\hline 14 & F12 & 0.728 & 151.99 & 0.00 & 208.77 & 443.63 & 6.46 \\
\hline 15 & F13 & 3.000 & 591.81 & 0.00 & 197.27 & $110^{30}$ & 6.10 \\
\hline 16 & F14 & 0.000 & 0.00 & -396.10 & 186.40 & 396.10 & $110^{30}$ \\
\hline 17 & F21 & 0.000 & 0.00 & -212.46 & 180.85 & 212.46 & $110^{30}$ \\
\hline 18 & $\mathrm{~F} 22$ & 0.000 & 0.00 & -200.76 & 170.88 & 200.76 & $110^{30}$ \\
\hline 19 & $\mathrm{~F} 23$ & 0.000 & 0.00 & -189.70 & 161.47 & 189.70 & $110^{30}$ \\
\hline 20 & $\mathrm{~F} 24$ & 0.000 & 0.00 & -179.25 & 152.57 & 179.25 & $110^{30}$ \\
\hline 21 & F31 & 2.718 & 602.58 & 0.00 & 221.73 & $1,246.72$ & 221.73 \\
\hline 22 & F32 & 2.718 & 569.39 & 0.00 & 209.51 & $1,246.72$ & 209.51 \\
\hline 23 & F33 & 2.733 & 541.12 & 0.00 & 197.97 & $1,400.64$ & 197.97 \\
\hline 24 & F34 & 3.000 & 561.20 & 0.00 & 187.07 & $110^{30}$ & 187.07 \\
\hline 25 & CV2 & 5.000 & $17,933.24$ & 0.00 & $3,586.65$ & $110^{30}$ & $2,288.13$ \\
\hline 26 & CV3 & 5.000 & $16,945.32$ & 0.00 & $3,389.06$ & $110^{30}$ & $2,193.57$ \\
\hline 27 & CV4 & 4.984 & $15,961.72$ & 0.00 & $3,202.37$ & $11,345.18$ & $2,042.98$ \\
\hline 28 & CI1 & 3.488 & $8,194.16$ & 0.00 & $2,349.39$ & 192.76 & 114.46 \\
\hline 29 & $\mathrm{CI} 2$ & 0.325 & 721.88 & 0.00 & $2,219.97$ & 182.14 & 12.41 \\
\hline 30 & $\mathrm{CI} 3$ & 1.477 & $3,097.80$ & 0.00 & $2,097.67$ & 172.11 & 11.73 \\
\hline 31 & $\mathrm{CI} 4$ & 0.343 & 679.08 & 0.00 & $1,982.11$ & 162.63 & 96.57 \\
\hline 36 & PP1 & 1.910 & $34,155.90$ & 0.00 & $17,879.45$ & 915.69 & $8,528.75$ \\
\hline 37 & PP2 & 1.282 & $21,664.09$ & 0.00 & $16,894.50$ & 865.24 & $2,111.50$ \\
\hline 38 & PP3 & 1.895 & $30,254.71$ & 0.00 & $15,963.80$ & 817.58 & $1,995.18$ \\
\hline 39 & PP4 & 1.263 & $19,047.59$ & 0.00 & $15,084.37$ & 772.54 & $7,195.45$ \\
\hline 40 & AL11 & 1.000 & -137.14 & 0.00 & -137.14 & 905.63 & $110^{30}$ \\
\hline 41 & AL12 & 1.000 & -129.58 & 0.00 & -129.58 & 855.74 & $110^{30}$ \\
\hline 42 & AL13 & 1.000 & -122.45 & 0.00 & -122.45 & 808.59 & $110^{30}$ \\
\hline 43 & AL14 & 1.000 & -115.70 & 0.00 & -115.70 & 764.05 & $110^{30}$ \\
\hline 44 & AL21 & 1.000 & -149.34 & 0.00 & -149.34 & 149.34 & $110^{30}$ \\
\hline 45 & AL22 & 1.000 & -141.11 & 0.00 & -141.11 & 141.11 & $110^{30}$ \\
\hline 46 & AL23 & 1.000 & -133.34 & 0.00 & -133.34 & 133.34 & $110^{30}$ \\
\hline 47 & AL24 & 1.000 & -125.99 & 0.00 & -125.99 & 125.99 & $110^{30}$ \\
\hline 48 & AJ1 & 3.000 & $7,610.33$ & 0.00 & $2,536.78$ & $110^{30}$ & 364.05 \\
\hline 49 & $\mathrm{AJ} 2$ & 0.000 & 0.00 & -10.99 & $2,397.03$ & 10.99 & $110^{30}$ \\
\hline 50 & $\mathrm{AJ} 3$ & 1.212 & $2,744.70$ & 0.00 & $2,264.98$ & 10.38 & 325.05 \\
\hline 51 & AJ4 & 0.000 & 0.00 & -683.32 & $2,140.20$ & 683.32 & $110^{30}$ \\
\hline 52 & ML11 & 3.000 & $11,657.47$ & 0.00 & $3,885.82$ & $110^{30}$ & 180.78 \\
\hline 53 & ML12 & 3.000 & $11,015.27$ & 0.00 & $3,671.76$ & $110^{30}$ & 170.82 \\
\hline 54 & ML13 & 3.000 & $10,408.45$ & 0.00 & $3,469.48$ & $110^{30}$ & 161.41 \\
\hline 55 & ML14 & 3.000 & $9,835.06$ & 0.00 & $3,278.35$ & $110^{30}$ & 152.52 \\
\hline 56 & ML21 & 3.000 & $11,594.29$ & 0.00 & $3,864.76$ & $110^{30}$ & $3,864.76$ \\
\hline 57 & ML22 & 3.000 & $10,955.58$ & 0.00 & $3,651.86$ & $110^{30}$ & $3,651.86$ \\
\hline 58 & ML23 & 3.000 & $10,352.05$ & 0.00 & $3,450.68$ & $110^{30}$ & $1,754.85$ \\
\hline 59 & ML24 & 3.000 & $9,781.77$ & 0.00 & $3,260.59$ & $110^{30}$ & $3,260.59$ \\
\hline \multicolumn{3}{|c|}{ Total $(\mathrm{U}-\mathrm{R} \$)$} & $372,723.16$ & & & & \\
\hline
\end{tabular}

(1) In the second column, the last figure of activity identification related to yearly cropping (from number 13 downwards) is showing the number of year. 
TABELA 5. Results on the linear programming, related to constraints on monthly water availability for irrigation $\left(\mathrm{V}_{\text {year, month }}\right)$, land $\left(\mathrm{T}_{\text {year, month }}\right)$, labor $\left(\mathrm{MO}_{\text {year, month }}\right)$ and production $\left(\mathrm{PR}_{\text {number of activities; }}\right.$, the number of activities are listed in the Table 4$)$.

\begin{tabular}{|c|c|c|c|c|c|}
\hline Constraint & $\begin{array}{l}\text { Shadow } \\
\text { Price }^{1} \\
\end{array}$ & $\begin{array}{c}\text { Constraint } \\
\text { Lateral R.H. }\end{array}$ & $\begin{array}{c}\text { Constraint } \\
\text { Unit }\end{array}$ & $\begin{array}{l}\text { Permissible } \\
\text { Increase }\end{array}$ & $\begin{array}{c}\text { Permissible } \\
\text { Decrease }\end{array}$ \\
\hline $\mathrm{V}_{1,4}$ & 0.131 & 15,000 & $\mathrm{~m}^{3}$ & 319.343 & $3,050.150$ \\
\hline $\mathrm{V}_{2,4}$ & 0.124 & 15,000 & $\mathrm{~m}^{3}$ & 868.170 & 284.374 \\
\hline $\mathrm{V}_{3,4}$ & 0.117 & 15,000 & $\mathrm{~m}^{3}$ & 961.217 & $1,291.482$ \\
\hline $\mathrm{V}_{3,9}$ & 1.421 & 15,000 & $\mathrm{~m}^{3}$ & 0.000 & 124.946 \\
\hline $\mathrm{V}_{4,4}$ & 0.110 & 15,000 & $\mathrm{~m}^{3}$ & 985.625 & 299.614 \\
\hline $\mathrm{T}_{1,12}$ & 221.729 & 19 & ha & 0.000 & 2.718 \\
\hline $\mathrm{T}_{2,12}$ & 209.515 & 19 & ha & 0.000 & 2.718 \\
\hline $\mathrm{T}_{3,12}$ & 197.973 & 19 & ha & 0.000 & 2.733 \\
\hline $\mathrm{MO}_{1,5}$ & 108.322 & 600 & days-man & 158.822 & 190.053 \\
\hline $\mathrm{MO}_{2,2}$ & 11.833 & 600 & days-man & 35.103 & 12.845 \\
\hline $\mathrm{MO}_{2,5}$ & 102.355 & 600 & days-man & 53.251 & 186.903 \\
\hline $\mathrm{MO}_{3,2}$ & 10.835 & 600 & days-man & 50.049 & 36.354 \\
\hline $\mathrm{MO}_{3,5}$ & 96.716 & 600 & days-man & 161.028 & 276.234 \\
\hline $\mathrm{MO}_{4,2}$ & 33.015 & 600 & days-man & 1.424 & 24.271 \\
\hline $\mathrm{MO}_{4,5}$ & 91.388 & 600 & days-man & 56.105 & 184.049 \\
\hline $\mathrm{PR}_{1}$ & -378.561 & 120 & t year ${ }^{-1}$ & 6.960 & 64.560 \\
\hline $\mathrm{PR}_{3}$ & 121.432 & 190 & $\mathrm{t}_{\text {crop }^{-1}}$ & 0.000 & 10.730 \\
\hline $\mathrm{PR}_{4}$ & 131.483 & 190 & 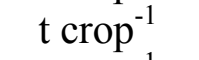 & 12.149 & 0.000 \\
\hline $\mathrm{PR}_{13}$ & 110.470 & 6 & $t_{\text {crop }}^{-1}$ & 5.435 & 6.000 \\
\hline $\mathrm{PR}_{15}$ & 3.052 & 6 & $t_{\text {crop }^{-1}}$ & 4.121 & 5.673 \\
\hline $\mathrm{PR}_{24}$ & 93.533 & 6 & $\mathrm{t}_{\text {crop }^{-1}}$ & 3.435 & 6.000 \\
\hline $\mathrm{PR}_{25}$ & 65.375 & 175 & ${\text { t } \text { crop }^{-1}}^{-1}$ & 4.940 & 9.883 \\
\hline $\mathrm{PR}_{26}$ & 62.673 & 175 & $\mathrm{t}_{\text {crop }^{-1}}$ & 13.982 & 9.883 \\
\hline $\mathrm{PR}_{48}$ & 22.753 & 48 & $t_{\text {crop }^{-1}}$ & 43.482 & 8.900 \\
\hline $\mathrm{PR}_{52}$ & 6.026 & 90 & $\mathrm{t}_{\text {crop }^{-1}}$ & 81.529 & 30.281 \\
\hline $\mathrm{PR}_{53}$ & 5.694 & 90 & ${\text { t } \text { crop }^{-1}}^{-1}$ & 10.402 & 76.759 \\
\hline $\mathrm{PR}_{54}$ & 5.380 & 90 & t crop $^{-1}$ & 47.239 & 81.886 \\
\hline $\mathrm{PR}_{55}$ & 5.084 & 90 & t crop $^{-1}$ & 10.959 & 76.501 \\
\hline $\mathrm{PR}_{56}$ & 128.825 & 90 & 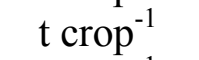 & 0.000 & 90.000 \\
\hline $\mathrm{PR}_{57}$ & 121.729 & 90 & 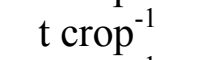 & 14.930 & 90.000 \\
\hline $\mathrm{PR}_{58}$ & 58.495 & 90 & $t_{\text {crop }}^{-1}$ & 3.140 & 0.000 \\
\hline $\mathrm{PR}_{59}$ & 108.686 & 90 & $t_{\text {crop }}^{-1}$ & 14.930 & 90.000 \\
\hline $\mathrm{PR}_{40}$ & -452.813 & 2 & ${\text { t } \text { crop }^{-1}}^{-1}$ & 5.435 & 2.000 \\
\hline $\mathrm{PR}_{41}$ & -427.868 & 2 & $t_{\text {crop }^{-1}}$ & 0.651 & 2.000 \\
\hline $\mathrm{PR}_{42}$ & -404.297 & 2 & $t_{\text {crop }^{-1}}$ & 2.956 & 2.000 \\
\hline $\mathrm{PR}_{43}$ & -382.025 & 2 & $t_{\text {crop }^{-1}}$ & 0.686 & 2.000 \\
\hline $\mathrm{PR}_{44}$ & -74.671 & 2 & ${\text { t } \text { crop }^{-1}}^{-1}$ & 7.435 & 2.000 \\
\hline $\mathrm{PR}_{45}$ & -70.557 & 2 & $t_{\text {crop }^{-1}}$ & 2.338 & 2.000 \\
\hline $\mathrm{PR}_{46}$ & -66.670 & 2 & $t_{\text {crop }^{-1}}$ & 7.435 & 2.000 \\
\hline $\mathrm{PR}_{47}$ & -62.997 & 2 & t crop $^{-1}$ & 2.382 & 2.000 \\
\hline
\end{tabular}

${ }^{1}$ Shadow price unit is $\mathrm{R} \$$ divided by the unit of the corresponding restriction.

As to activities exhibited in the optimal solution, it can be seen in Table 4 the variability about the sensitivity of the objective-function coefficients. For lemon cropping (L1), the permissible increase and decrease were $\mathrm{R} \$ 1,290.12$ and $\mathrm{R} \$ 1,246.72$ per hectare, respectively, i.e., about $20 \%$ of the value of the respective objective-function coefficient. Otherwise, banana cropping (B1) exhibited a permissible increase of $\mathrm{R} \$ 13,249.64$ per hectare, i.e., $15,184 \%$ higher than the 
objective-function coefficient ( $\mathrm{R} \$ 87.26$ per hectare). The permissive decrease tends to infinite, as this activity is present in the optimal solution, due to the minimum production constraint, as shown in Table 3. Therefore, banana cropping is indicated as a stable activity (low sensitivity referred to the objective-function coefficient) in the optimal solution.

Constraints about irrigation water availability on a yearly basis were not limiting in anyone of the four years of the analysis horizon, on the contrary of the water availability on monthly basis, as it can be seen in Table 5 . The shadow prices related to the water monthly availability changed from $\mathrm{R} \$ 0.12 \mathrm{~m}^{-3}$ (April of fourth year) to $\mathrm{R} \$ 1.42 \mathrm{~m}^{-3}$ (September of third year). Constraints about labor and production could have caused reductions on shadow prices for the water monthly availability.

Constraint about land reduced production in December in the years 1 to 3 . Shadow prices varied from R\$ 197.97 to $\mathrm{R} \$ 221.73$ per hectare. Shadow prices for labor reached the value of $\mathrm{R} \$ 108.32$ per man-day in the month 5 of first year. Model could then be rebuilt increasing labor availability in the critical months, so as making it closer to real situation, where hiring extra labor is possible.

As to the constraints related to production, negative shadow prices were obtained, corresponding to banana and cotton cropping, which are shown in the optimal solution due to the constraint about the minimum production. Constraints about the maximum production of bean (crop 1 of years 1 and 3 and crop 3 of year 4), summer onion (years 2 and 3), hybrid pumpkin (year 1) and melon (crops 1 and 2 of every year) were also significant.

In Table 5, it can be observed the constraint about water monthly availability was acting in April month for all four years of planning horizon. Aiming to reduce uncertainties about the water availability of these months, other cropping patterns were obtained through the optimization of the objective-function expressed by eq.(2), taking into account the equality constraint for the total net present value (U), described by eq.(3). Total irrigation water requirement (Wt), considered in eq.(2), was the addition of the four months of April. In Figure 3, this procedure is exhibited, showing the minimum Wt line, analog to $\mathrm{AC}$ line as showed in Figure 2. It can be observed $0.7 \%$ reduction in $\mathrm{U}$ from the value obtained with eq.(1) ( $\mathrm{R} \$ 372,723.00$ ) caused a significant reduction of $19 \%$ at $\mathrm{Wt}$, showing the potential of planning strategy adopted viewing to hydric demand adequacy, especially on critical periods of water availability.

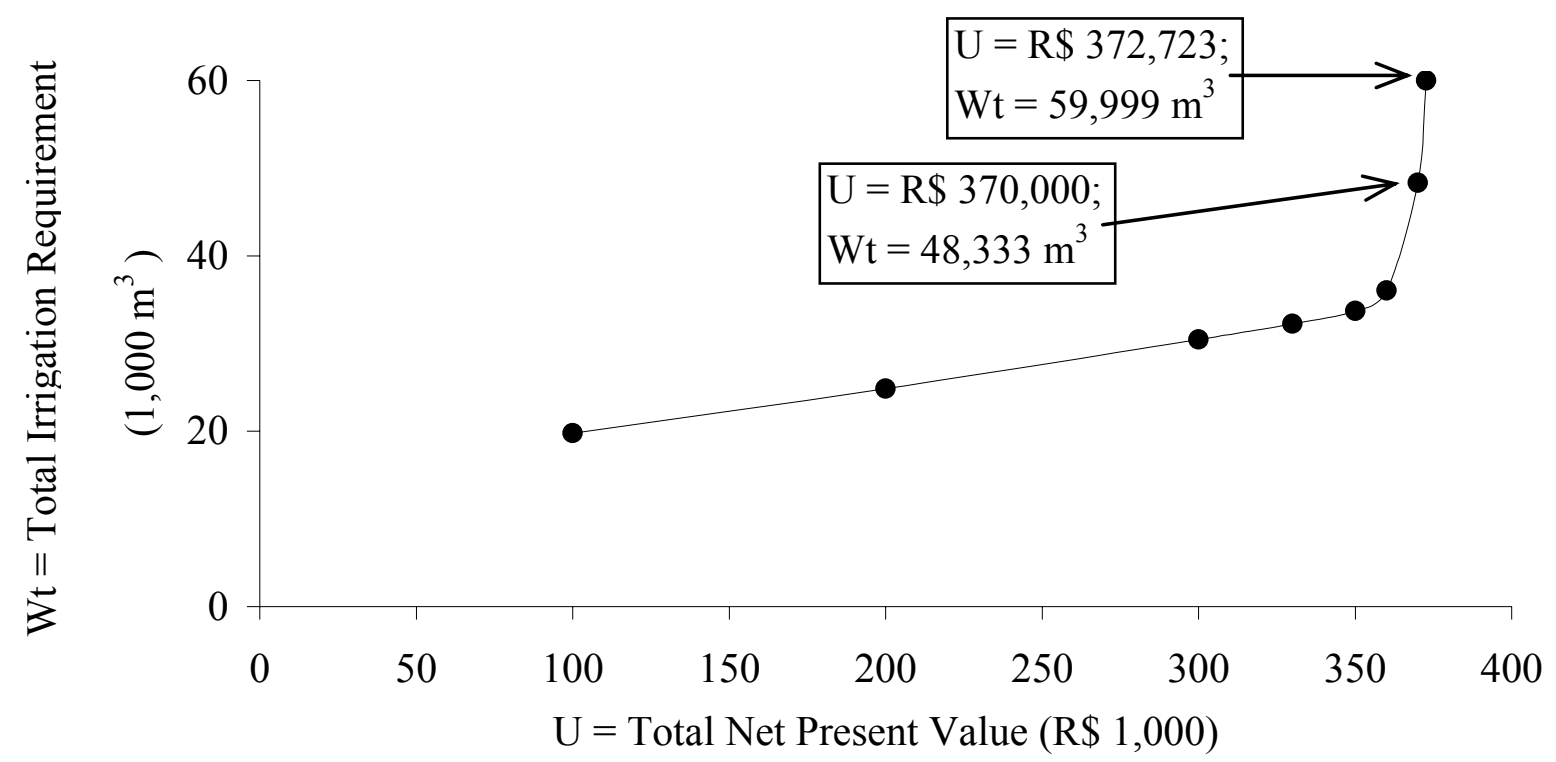

FIGURE 3. Line of minimum total irrigation requirement (total for the April months of the four years) in the U vs Wt plan. 


\section{CONCLUSIONS}

The linear programming model as developed here shows a cultivation pattern for which the maximum total net present value is obtained, equal to $\mathrm{R} \$ 372,723.00$ for the period of four years. Constraints about monthly availability of water, labor, land and production were acting in optimum solution.

Related to the water use optimization, it can be verified significant reductions in irrigation requirement can be obtained with little reductions in the maximum total net present value, showing the potential of planning strategy adopted viewing to hydric demand adequacy in the critical periods of water availability.

\section{ACKNOWLEDGEMNTS}

To CNPq, Capes and DAAD, for the financial support. To the Center for Development Research - ZEF, Germany, to Embrapa Milho e Sorgo and to UFV, for the support to works development.

\section{REFERENCES}

ALLEN, R.G.; PEREIRA, L.S.; RAES, D.; SMITH, M. Crop evapotranspiration - Guidelines for computing crop water requirements. Rome: FAO, 1998. 300 p. (Paper 56).

BORGES JÚNIOR, J.C.F. Modelo computacional para tomada de decisão em agricultura irrigada. 2004. 226 f. Tese (Doutorado em Recursos Hídricos e Ambientais) - Universidade Federal de Viçosa, Viçosa, 2004.

BORGES JÚNIOR, J.C.F.; FERREIRA, P.A.; HEDDEN-DUNKHORST, B.; ANDRADE, C.L.T. Modelo computacional para suporte à decisão em áreas irrigadas. Parte I: Desenvolvimento e análise de sensibilidade. Revista Brasileira de Engenharia Agrícola e Ambiental, Campina Grande, v.12, n.1, p.3-11, 2008.

BORGES JÚNIOR, J.C.F.; HEDDEN-DUNKHORST, B.; FERREIRA, P.A. Decision support based on bio-economic simulations for irrigated agriculture. In: DEUTSCHER TROPENTAG CONFERENCE ON INTERNATIONAL AGRICULTURAL RESEARCH FOR DEVELOPMENT. Göttingen, out. 2003. Disponível em:

<http://www.tropentag.de/2003/abstracts/full/224.pdf>. Acesso em: 23 jan. 2007.

CARVALLO, H.O.; HOLZAPFEL, E.A.; LOPEZ, M.A.; MARIÑO, M.A. Irrigated cropping optimization. Journal of Irrigation and Drainage Engineering, Delaware, v.124, n.2, p.67-72, 1998.

CARVALHO, D.F.; SOARES, A.A.; RIBEIRO, C.A.A.S.; SEDIYAMA, G.C.; PRUSKI, F.F. Otimização do uso da água no perímetro irrigado do Gorutuba, utilizando-se da técnica da programação linear. Revista Brasileira de Engenharia Agrícola e Ambiental, Campina Grande, v.4, n.2, p.203-9, 2000.

DANTAS NETO, J.; AZEVEDO, C.A.V.; FRIZZONE, J.A. Uso da programação linear para estimar o padrão de cultura do perímetro irrigado Nilo Coelho. Revista Brasileira de Engenharia Agrícola e Ambiental, Campina Grande, v.1, n.1, p.9-12, 1997.

FERREIRA, P.A.; BORGES JÚNIOR, J.C.F.; HEDDEN-DUNKHORST, B.; ANDRADE, C.L.T. Modelo computacional para suporte à decisão em áreas irrigadas. Parte II: Testes e aplicação. Revista Brasileira de Engenharia Agrícola e Ambiental, Campina Grande, v.10, n.4, p.783-91, 2006.

FRIZZONE, J.A.; ANDRADE JÚNIOR, A.S.; SOUZA, J.L.M.; ZOCOLER, J.L. Planejamento de irrigação. Análise de decisão de investimento. Brasília: Embrapa Informação Tecnológica, 2005, $626 \mathrm{p}$. 
HAZELL, P.B.R.; NORTON, R.D. Mathematical programming for economic analysis in agriculture. New York: Macmillan Publishing Company, 1986. 400 p.

MEINKE, H.; BAETHGEN, W.E.; CARBERRY, P.S.; DONATELLI, M.; HAMMER, G.L.; SELVARAJU, R.; STÖCKLE, C.O. Increasing profits and reducing risks in crop production using participatory systems simulation approaches. Agricultural Systems, Amsterdam, v.70, n.4, p.493$513,2001$.

QUARESMA FILHO, M.I.M. Avaliação dos sistemas de irrigação por microaspersão na fruticultura dos projetos Gorutuba e Jaíba. 2000. 85 f. Dissertação (Mestrado em Recursos Hídricos e Ambientais) - Universidade Federal de Viçosa, Viçosa, 2000.

SILVEIRA, S.F.R. Análise econômica da agricultura irrigada: projeto Jaíba. 1993. 145 f. Dissertação (Mestrado em Economia Aplicada) - Universidade Federal de Viçosa, Viçosa, 1993.

SKAGGS, R.W. Drainage simulation models. In: SKAGGS, R.W.; SCHILFGAARDE, J. van. Agricultural drainage. Madison: American Society of Agronomy, 1999. p.469-500.

TARJUELO, J.M.; JUAN, J.A. Crop water management. In: LIER, H.N. van; PEREIRA, L.S.; STEINER, F.R. CIGR handbook of agricultural engineering: land and water engineering. St. Joseph: American Society of Agricultural Engineers, 1999. p.380-429.

UNIVERSITY OF IDAHO. REF-ET Reference evapotranspiration calculation software for FAO and ASCE standardized equations. Out. 2003. Disponível em:

$<$ http://www.kimberly.uidaho.edu/ref-et/>. Acesso em: 10 abr. 2008. 